\title{
Analisis Tingkat Efektivitas Sistem Informasi Akademik IAIN Syaikh Abdurrahman Siddik Bangka Belitung
}

\author{
Priyanggo Karunia Rahman \\ IAIN Syaikh Abdurrahman Siddik Bangka Belitung; \\ Bangka, Indonesia; \\ priyanggo@,iainsasbabel.ac.id, \\ Lussiana ETP \\ Universitas Gunadarma; \\ Jakarta, Indonesia; \\ ussie@staff.gunadarma.ac.id
}

\begin{abstract}
IAIN Syaikh Abdurrahman Siddik Bangka Belitung implements an academic information system at located at http://ecampus.iainsasbabel.ac.id. In the academic system, there is some information that can be obtained by students. All menus contained in the academic system of IAIN Syaikh Abdurrahman Siddik Bangka Belitung are very beneficial for the campus, especially for students. With regard, it is necessary to measure the level of effectiveness of the academic information system application IAIN Syaikh Abdurrahman Siddik Bangka Belitung. To measure the level of effectiveness of the academic information system IAIN SAS Bangka Belitung then used standard the ISO 9126 with indicators of Functionality, Reliability, Usability, and Efficiency. The results showed that the four indicators of the standard ISO 9126 provide sufficiently effective, and efficient for the students in the use of Academic Information Systems.
\end{abstract}

IAIN Syaikh Abdurrahman Siddik Bangka Belitung menerapkan sistem informasi akademik yang beralamat http://ecampus.iainsasbabel.ac.id. Di dalam sistem informasi akademik ini terdapat beberapa informasi yang bisa didapat oleh mahasiswa. Seluruh menu yang terdapat dalam sistem akademik IAIN Syaikh Abdurrahman Siddik Bangka Belitung yang disiapkan sangat bermanfaat bagi kampus terutama bagi mahasiswa. Berkaitan dengan hal tersebut perlu diukur tingkat efektivitas dari aplikasi sistem informasi akademik IAIN Syaikh Abdurrahman Siddik Bangka Belitung. Untuk mengukur tingkat efektivitas sistem informasi akademik IAIN Syaikh Abdurrahman Siddik Bangka Belitung digunakan standart ISO 9126 dengan indikator Functionality, Reliability, Usability dan Efficiency. Hasil penelitian menunjukkan bahwa empat variabel ISO 9126 memberikan hasil cukup efektif dan efisien bagi mahasiswa dalam penggunaan Sistem Informasi Akademik.

Keywords: (Academic Information System, Efektivitas, ISO 9126) 
|PRIYANGgO KAUNIA RAHMAN | Analisis Tingkat Efektivitas Sistem...

\section{A. Pendahuluan}

Sekolah Tinggi Agama Islam Negeri (STAIN) Bangka Belitung dalam pelayanan akademik sejak tahun 2008 masih dilakukan secara manual. Kondisi ini menimbulkan berbagai masalah, yaitu banyak antrian mahasiswa di kampus yang ingin regristasi ulang, sehingga terlambatnya pembagian KHS (Kartu Hasil Studi) yang mengakibatkan mahasiswa belum bisa menentukan jumlah SKS yang akan diambil dalam pengisian FRS (Formulir Rencana Studi). Jumlah mahasiswa yang aktif tidak dapat ditentukan dengan pasti dan mengakibatkan ketidak sinkronan data antara bagian keuangan dengan bagian akademik. Kalender akademik yang selalu berubah juga membuat mundur dalam menentukan dimulainya perkuliahan, dan terlambatnya pelaporan PDDikti.

STAIN Bangka Belitung mulai dituntut untuk mengembangkan layanan akademik berbasis teknologi informasi agar dapat mempermudah kelancaran layanan akademik pada tahun 2010. Setelah tahun 2018 STAIN resmi menjadi Institut Agama Islam Negeri (IAIN) berdasarkan Keputusan Presiden RI. Pada saat ini IAIN Syaikh Abdurrahman Siddik Bangka Belitung menggunakan aplikasi Sistem Informasi Akademik yang bernama ecampus diharapkan proses layanan akademik menjadi lebih efektif dan efisien. Oleh sebab itu maka penerapan aplikasi ecampus di IAIN Syaikh Abdurrahman Siddik Bangka Belitung perlu dilakukan pengukuran tingkat efektifitas.

Efektivitas adalah kemampuan suatu sistem aplikasi untuk melakukan aktivitas agar pengguna dapat mencapai tujuan yang maksimal. Dalam pengukuran efektivitas sistem informasi terdapat berbagai cara pengukuran tingkat efektifitas sistem informasi, diantaranya (Rozas dan Effendy 2012) ${ }^{1}$ melakukan pengukuran efektivitas hasil audit teknologi informasi menggunakkan framework COBIT 4.1 hasil penelitian menunjukkan bahwa persentase kesamaan antara Audit TI menggunakan RACI chart dan Audit TI dengan perspektif end user adalah 100\%. Dengan demikian dapat disimpulkan bahwa keterlibatan end user dalam proses audit

\footnotetext{
${ }^{1}$ Indri Sudanawati Rozas and Danar Ayu Ristyantie Effendy, "Mengukur Efektifitas Hasil Audit Teknologi Informasi COBIT 4.1 Berdasarkan Perspektif End User," Jurnal Link 17 (2012).
} 
teknologi informasi tidak terlalu signifikan. (Rewah dan Rotikan 2016) ${ }^{2}$ melakukan pengukuran efektivitas sistem informasi di kantor badan Kepegawaian dan Diklat Kota Manado dengan menggunakan metode Total Quality Management hasil penelitian menunjukkan bahwa variabel independent Reliability, Responsiveness dan Assurance menunjukan berpengaruh secara posistif dan signifikan, dan dua variable Emphaty dan Tangibles tidak berpengaruh secara signifikan, tetapi secara serentak berpengaruh secara signifikan, (Mesa dan Andry 2018) ${ }^{3}$ melakukan Evaluasi Tingkat Efektivitas sistem informasi dengan menggunakan capability model pada framework COBIT 5 mengukur level kapabilitas Manage Operation (DSS01) dan Manage Problem (DSS03) hasil penelitian menunjukkan DSS01 dan DSS03 berada pada nilai 2.4. sehingga hasil tingkat capability level berjalan dengan baik dan efektif namun masih perlu melakukan beberapa perbaikan untuk meningkatkan capability level yang ada. (Muhsin and Pratama 2018) ${ }^{4}$ menganalisis efektivitas pendingin, dengan metode approach dan range dalam pengukuran efektivitas. Hasil penelitian diperoleh nilai rata-rata OEE mesin cooling tower sebesar $>85 \%$ yang berarti telah memenuhi standar world class dan layak untuk dipergunakan, beberapa titik memiliki nilai kurang dari standar dengan nilai terendah $81 \%$ disebabkan karena lamanya waktu downtime. Dengan demikian perusahaan perlu menerapkan perawatan preventif yang rutin dan tepat waktu untuk mempertahankan performansi Cooling Tower. Berdasarkan pada kondisi yang telah diuraikan, maka penelitian ini dilakukan untuk mengukur tingkat efektivitas sistem informasi akademik di IAIN Syaikh Abdurrahman Siddik Bangka Belitung dengan menggunakan metode kuantitatif deskriptif.

\footnotetext{
${ }^{2}$ Jein Rewah and Reymon Rotikan, "Analisa Efektivitas Sistem Informasi Di Kantor Badan Kepegawaian Dan Diklat Kota Manado,” CogITo Smart Journal 2, no. 2 (2016): 180-93.

${ }^{3}$ Budi Hartono Mesa and Johanes Fernandes Andry, "Evaluasi Tingkat Efektivitas Sistem Informasi Menggunakan Framework COBIT 5,” 2018.

${ }^{4}$ Ahmad Muhsin and Zicko Pratama, "Analisis Efektivitas Mesin Cooling Tower Menggunakan Range and Approach," Opsi 11, no. 2 (2018): 119-24.
} 
|PRIYANGGO KAUNIA RAHMAN | Analisis Tingkat Efektivitas Sistem...

\section{B. Metode Penelitian}

Penelitian ini menggunakan metode kuantitatif deskriptif terhadap variabel dari ISO 9126. Adapun tahapan-tahapan dalam metode kuantitatif. Dapat dilihat pada gambar 1 menjelaskan tentang tahapan proses penelitian yang akan dilakukan oleh peneliti, adalah model waterfall yang terdiri dari 4 tahap yaitu: Analisis, Desain (Perancangan), Implementasi dan Pengujian.

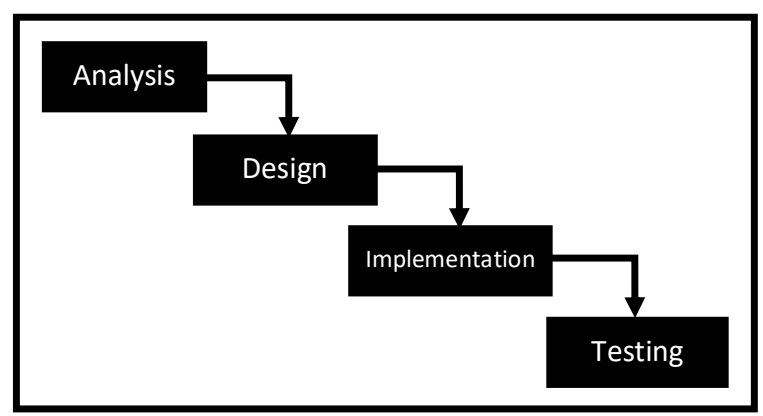

Gambar 1. Alur Proses Penelitian

\section{Tahap Analisis}

Tahap analisis pada penelitian ini ada dua proses yaitu analisis kebutuhan dan analisis data. Analisis kebutuhan yaitu dengan melakukan studi literatur sedangkan analisis data dengan melakukan pengambilan data melalui wawancara dan observasi serta perhitungan sampel.

\subsection{Analisis Kebutuhan}

Pada analisis kebutuhan dilakukan studi literatur dan penelitian serta jurnal yang terkait. Sehingga didapatkan pemahaman tentang melakukan pengukuran efektifitas dan efisiensi sistem informasi akademik adalah sebagai berikut: Model Kuantitatif Deskriptif, Rumus Slovin, Penentuan Variabel Penelitian.

\subsection{Analisis Data}

Pengumpulan data adalah teknik atau cara yang dilakukan oleh peneliti untuk mengumpulkan data. Dalam mengumpulkan data melalui wawancara melakukan tanya jawab langsung antara peneliti kepada narasumber. Observasi yaitu 
aktivitas terhadap suatu objek dengan merasakan dan kemudian memahami, serta pemilihan sampel menggunakan teknik probability sampling salah satunya yaitu teknik sample random sampling. Sampel yang menjadi sasaran adalah mahasiswa aktif IAIN Syaikh Abdurrahman Siddik Bangka Belitung dengan menggunakan taraf kesalahan 5\% untuk menentukan jumlah sampel yang dipilih menggunakan tingkat kesalahan sebesar 5\% karena pada setiap penelitian tidak mungkin hasilnya sempurna $100 \%$. hasil perhitungan sampel yang akan digunakan dalam pengumpulan kuesioner ini berjumlah sebanyak 138 responden. Diharapkan dari jumlah sampel tersebut dapat mewakili keseluruhan populasi dan dapat menghasilkan hasil yang relevan.

\section{Tahap Design}

Dalam tahap ini dibuat parameter ukuran untuk nilai-nilai efektivitas dan menyusun pertanyaan-pertanyaan untuk kuesioner yang akan digunakan berdasarkan Model ISO 9126, Setelah menentukan variabel dan indikator penelitian, langkah selanjutnya adalah menyusun kuisioner dengan beberapa pernyataan yang sesuai dengan indikator-indikator pada setiap variabel. Pernyataan kuisioner dari variabel ISO 9126 dapat dilihat pada Tabel 1

Tabel 1 Pernyataan dari Variabel ISO 9126

\begin{tabular}{lll}
\hline Karakteristik & Set Model & Parameter \\
\hline \multirow{3}{*}{ Fungsionality } & Suitability & $\begin{array}{l}\text { Fungsi data, Fungsi Pengolahan dan Fungsi } \\
\text { output }\end{array}$ \\
\cline { 2 - 3 } & Accuracy & $\begin{array}{l}\text { Keakuratan pengolahan data dan Keakuratan } \\
\text { dalam menampilkan dat }\end{array}$ \\
\cline { 2 - 3 } & Interoperability & $\begin{array}{l}\text { Kemampuan komputer /software berinteraksi } \\
\text { dengan komponen atau sistem lainnya }\end{array}$ \\
\cline { 2 - 3 } Realiability & Security & Keamanan simpan data \\
\cline { 2 - 3 } & Maturity & Model maturity \\
\cline { 2 - 3 } & Fecoverability & Kesalahan dalam penggunaan aplikasi \\
\hline \multirow{3}{*}{ Usability } & understandability & Fitur-fitur dalam aplikasi ini mudah digunakan \\
\cline { 2 - 3 } & Learnability & Cara installs, Cara konfigurasi \\
\cline { 2 - 3 } & Operability & Pengoperasian Open Help Exit \\
\hline
\end{tabular}


|PRIYANGGO KAUNIA RAHMAN | Analisis Tingkat Efektivitas Sistem...

\begin{tabular}{lll}
\hline & Attractiveness & User interface form-form tampilannya \\
\hline Efficiency & Time behavior & waktu proses transaksi \\
\hline
\end{tabular}

\section{Implementasi}

Pada tahap ini dilakukan implementasi dari parameter ukuran nilai dengan membuat pertanyaan-pertanyaan yang sesuai berdasarkan ISO 9126, sehingga menghasilkan pernyataan-pernyataan yang akan diujikan pada tahap selanjutnya.

\section{Pengujian}

Pada tahap pengujian ini sistem informasi akan diuji kemudian dilakukan pengujian dengan cara menyebarkan kuesioner ke pengguna (mahasiswa). Instrumen penelitian terdiri dari functionality, reliability, usability dan efficiency.

\section{Hasil dan Pembahasan}

Gambaran efektivitas ecampus IAIN Syaikh Abdurrahman Siddik Bangka Belitung dalam penelitian ini diukur dengan menggunakan empat kriteria yaitu functionality, Reliability, Usability dan Efficiency. Adapun deskripsi dari keempat kriteria berdasarkan jawaban responden adalah sebagai berikut:

\section{Functionality}

Fungsionality dari kualitas sistem informasi berdasarkan pada indikator suitability, accuracy, interoperability dan security dari sistem layanan akademik ecampus IAIN Syaikh Abdurrahman Siddik Bangka Belitung deskripsinya adalah sebagai berikut:

\subsection{Suitability}

Berdasarkan Tabel 2 menunjukkan bahwa rata-rata (mean) suitability ecampus sebesar 17,94 dengan nilai maksimum adalah 24 dan nilai minimium adalah 11. Standart deviasi dari data ini adalah 2,412. Hasil analisis tersebut menunjukkan nilai standar deviasi lebih rendah dari pada nilai rata-rata maka sebaran data yang rendah dan tidak adanya kesenjangan yang cukup besar dari nilai tertinggi dan nilai 
terendah. Hal ini menunjukkan bahwa aplikasi ecampus telah menyediakan fungsi tombol input, fungsi pengolahan dan fungsi output.

Tabel 2. Descriptive Statistic Suitability

\section{Descriptive Statistic}

\begin{tabular}{cc}
\hline Mean & 17,94 \\
Standard Deviation & 2,412 \\
Minimum & 11 \\
Maximum & 24 \\
Responden & 138 \\
\hline
\end{tabular}

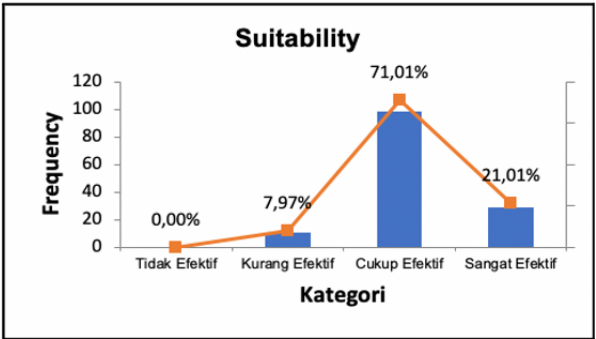

Gambar 2. Grafik Suitability

Sebaran data pada gambar 2 dapat menjelaskan bahwa suitability ecampus berada pada kategori kesesuaian cukup efektif sebesar 71,01\% dan kriteria sangat efektif sebesar $21,01 \%$, sehingga jika dijumlahkan mendapatkan prosentase sebesar $81,02 \%$ dari 138 responden yang menjawab setuju bahwa aplikasi sesuai dan telah memenuhi kebutuhan atau keinginan pengguna.

\subsection{Accuracy}

Berdasarkan Tabel 3 menunjukkan bahwa rata-rata (mean) accuracy adalah 11,78 dengan nilai maksimum adalah 16 dan nilai minimium adalah 7, standart deviation atau standar deviasi adalah 1,889. Hasil analisis tersebut menunjukkan nilai standar deviasi lebih rendah dari pada nilai rata-rata maka sebaran data yang rendah dan tidak adanya kesenjangan yang cukup besar dari nilai tertinggi dan terendah. Hal ini menunjukkan bahwa aplikasi ecampus telah akurat dalam mengolah data dan menampilkan data.

Tabel 3. Descriptive Statistic Accuracy

\begin{tabular}{cc}
\hline \multicolumn{2}{c}{ Descriptive Statistic } \\
\hline Mean & 11,78 \\
Standard Deviation & 1,889 \\
Minimum & 7 \\
Maximum & 16 \\
Responden & 138 \\
\hline
\end{tabular}

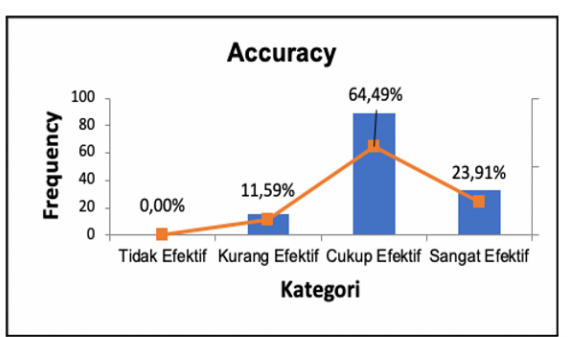

Gambar 3. Grafik Accuracy 
Sebaran data pada gambar 3 dapat menjelaskan bahwa accuracy ecampus berada pada kategori akurasi cukup efektif sebesar 64,49 dan kriteria sangat efektif besarannya $23,91 \%$, maka nilai tersebut dijumlahkan menghasilkan prosentase sebesar $86,4 \%$ dari 138 responden yang menjawab setuju bahwa aplikasi tersebut mampu melakukan proses pengolahan data (simpan, edit, hapus, tampil data) secara tepat.

\subsection{Interoperability}

Berdasarkan Tabel 4 menunjukkan bahwa rata-rata (mean) interoperability adalah 20 dengan nilai maksimum adalah 28 dan nilai minimium adalah 9, standart deviation atau standar deviasi adalah 3,57. Hasil analisis tersebut menunjukkan nilai standar deviasi lebih rendah dari pada nilai rata-rata maka sebaran data yang rendah dan tidak adanya kesenjangan yang cukup besar dari nilai tertinggi dan terendah. Hal ini menunjukkan bahwa aplikasi ecampus dapat berinteraksi atau terhubung dengan komponen lainnya.

Tabel 4. Descriptive Statistical Interoperability

\begin{tabular}{lc}
\hline \multicolumn{2}{c}{ Descriptive Statistic } \\
\hline Mean & 20 \\
Standard Deviation & 3,570 \\
Minimum & 9 \\
Maximum & 28 \\
Responden & 138 \\
\hline
\end{tabular}

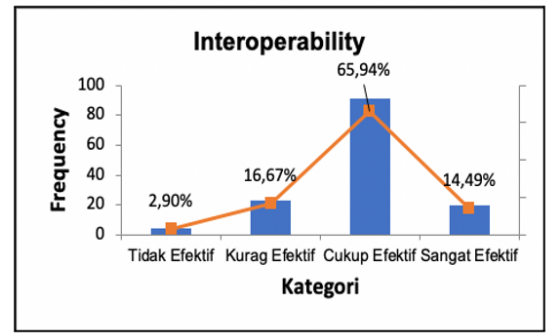

Gambar 4. Grafik Interoperabiliy

Sebaran data pada gambar 4 menjelaskan bahwa aplikasi ecampus berada pada kategori cukup efektif sebesar 65,94\% dan sangat efektif sebesar 14,49\%, sehingga nilai tersebut dijumlahkan menghasilkan prosentase sebesar $80,43 \%$ dari 138 responden/mahasiswa yang menjawab setuju bahwa aplikasi mampu berinteraksi dengan komponen aplikasi lain.

\subsection{Security}

Berdasarkan Tabel 5 menunjukkan bahwa rata-rata (mean) security adalah 6,13 dengan nilai maksimum adalah 8 dan nilai minimium adalah 4 , standart 
deviation atau standar deviasi adalah 0,852. Hasil analisis tersebut menunjukkan nilai standar deviasi lebih rendah dari pada nilai rata-rata maka sebaran data yang rendah dan tidak adanya kesenjangan yang cukup besar dari nilai tertinggi dan terendah. Hal ini menunjukkan bahwa aplikasi ecampus dapat menjaga keamanan dalam menyimpan data.

Tabel 5. Descriptive Statistic Security

\begin{tabular}{lc}
\hline \multicolumn{2}{c}{ Descriptive Statistic } \\
\hline Mean & 6,13 \\
Standard Deviation & 0,852 \\
Minimum & 4 \\
Maximum & 8 \\
Responden & 6,13 \\
\hline
\end{tabular}

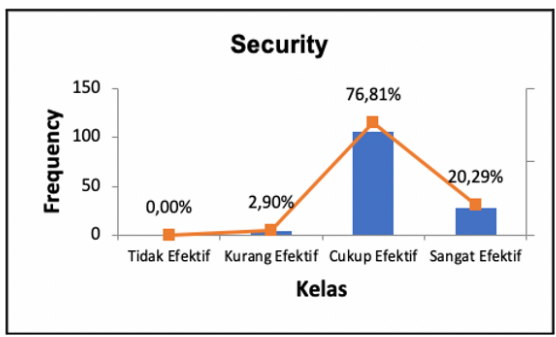

Gambar 5. Grafik Security

Sebaran data pada Gambar 5 menjelaskan bahwa security aplikasi ecampus berada pada kategori cukup efektif sebesar 76,81\% sedangkan sangat efektif sebesar 20,29\%, jika kedua kategori dijumlahkan menghasilkan prosentase sebesar 97,1\% dari 138 responden /mahasiswa yang menjawab setuju bahwa aplikasi mampu mengontrol akses pengguna dan membatasi hak akses.

\section{Reliability}

Reliability dari kualitas sistem informasi berdasarkan pada indikator maturity, fault tolerance, dan recoverability dari sistem layanan akademik ecampus IAIN Syaikh Abdurrahman Siddik Bangka Belitung deskripsinya adalah sebagai berikut:

\subsection{Maturity}

Berdasarkan Tabel 6 menunjukkan bahwa rata-rata (mean) maturity aplikasi ecampus adalah 2,76 dengan nilai maksimum adalah 4 dan nilai minimium adalah 1 , standart deviation atau standar deviasi adalah 0,697. Hasil analisis tersebut menunjukkan nilai standar deviasi lebih rendah dari pada nilai rata-rata maka sebaran data yang rendah dan tidak adanya kesenjangan yang cukup besar dari nilai tertinggi 
dan terendah. Hal ini menunjukkan kemampuan sistem aplikasi mampu terhindar kesalahan (error).

Tabel 6. Descriptive Statistic Maturity

\begin{tabular}{lc}
\hline \multicolumn{2}{c}{ Descriptive Statistic } \\
\hline Mean & 2,76 \\
Standard Deviation & 0,697 \\
Minimum & 1 \\
Maximum & 4 \\
Responden & 138 \\
\hline
\end{tabular}

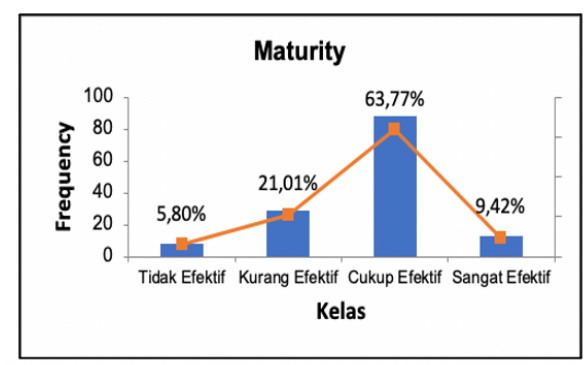

Gambar 6. Grafik Maturity

Sebaran data pada Gambar 6 menjelaskan bahwa maturity berada pada kategori cukup efektif sebesar $63,77 \%$ sedangkan sangat efektif sebesar 9,42\%, maka prosentase diatas dijumlahkan sebesar $73,19 \%$ dari 138 responden yang menjawab setuju bahwa aplikasi ecampus menghindari error proses data.

\subsection{Fault Tolerance}

Berdasarkan Tabel 7 menunjukkan bahwa rata-rata (mean) fault tolerance adalah 2,44 dengan nilai maksimum adalah 4 dan nilai minimium adalah 1, standart deviation atau standar deviasi adalah 0,764. Hasil analisis tersebut menunjukkan nilai standar deviasi lebih rendah dari pada nilai rata-rata maka sebaran data yang rendah dan tidak adanya kesenjangan yang cukup besar dari nilai tertinggi dan terendah. Nilai ini menunjukkan kemampuan sistem aplikasi dapat tetap beroperasi dengan baik jika terjadi kesalahan.

Tabel 7. Descriptive Statistic Fault Tolerance

\begin{tabular}{lc}
\hline \multicolumn{2}{c}{ Descriptive Statistic } \\
\hline Mean & 2,44 \\
Standard Deviation & 0,764 \\
Minimum & 1 \\
Maximum & 4 \\
Responden & 138 \\
\hline
\end{tabular}

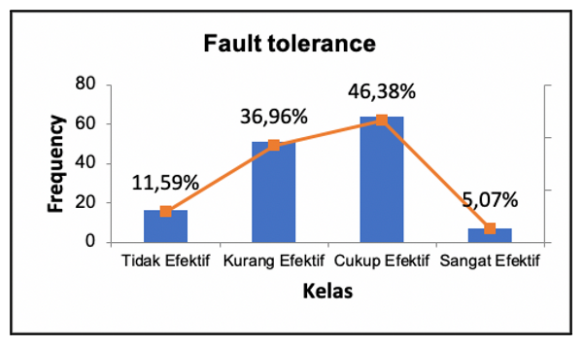

Gambar 7. Grafik Fault tolerance 
Sebaran data pada gambar 7 dapat diketahui bahwa fault tolerance berada pada kategori cukup efektif sebesar 46,38\% sedangkan sangat efektif sebesar 5,07\%, maka penjumlahan dari dua kategori diatas menghasilkan sebesar 51,45 dari 138 responden yang menjawab setuju bahwa aplikasi masih bisa berjalan bila terjadi kesalahan, baik dalam proses login maupun pengolahan data (simpan, edit, hapus, tampil data).

\subsection{Recoverability}

Berdasarkan Tabel 8 menunjukkan bahwa rata-rata (mean) recoverability adalah 2,84 dengan nilai maksimum adalah 4 dan nilai minimium adalah 1, standart deviation atau standar deviasi adalah 0,693. Hasil analisis tersebut menunjukkan nilai standar deviasi lebih rendah dari pada nilai rata-rata maka sebaran data yang rendah dan tidak adanya kesenjangan yang cukup besar dari nilai tertinggi dan terendah. Nilai ini menunjukkan kemampuan aplikasi memperbaiki data dalam aplikasi tersebut.

Tabel 8. Descriptive Statistic Recoverability

\begin{tabular}{lc}
\hline \multicolumn{2}{c}{ Descriptive Statistic } \\
\hline Mean & 2,84 \\
Standard Deviation & 0,693 \\
Minimum & 1 \\
Maximum & 4 \\
Responden & 138 \\
\hline
\end{tabular}

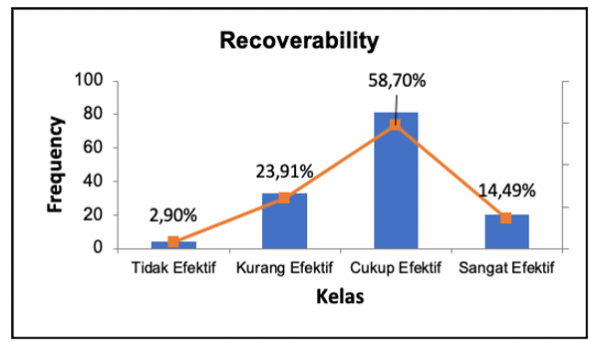

Gambar 8. Grafik Recoverability

Sebaran data pada Gambar 8 menjelaskan bahwa bahwa Recoverability berada pada kategori cukup efektif sebesar $58,7 \%$ sedangkan sangat efektif sebesar 14,49\%, maka gabungan kedua kategori menghasilkan 73,19\% dari 138 responden yang menjawab setuju bahwa aplikasi mampu memperbaiki sendiri jika terjadi kesalahan. 
|PRIYANGgO KAUNIA RAHMAN | Analisis Tingkat Efektivitas Sistem...

\section{Usability}

Usability dari kualitas sistem informasi berdasarkan pada indikator understandability, learnability, operability dan attractiveness dari sistem layanan akademik ecampus IAIN Syaikh Abdurrahman Siddik Bangka Belitung deskripsinya adalah sebagai berikut:

\subsection{Understandability}

Berdasarkan Tabel 9 menunjukkan bahwa rata-rata (mean) understandability adalah 17,15 dengan nilai maksimum adalah 24 dan nilai minimium adalah 6, standart deviation atau standar deviasi adalah 3,526. Hasil analisis tersebut menunjukkan nilai standar deviasi lebih rendah dari pada nilai ratarata maka sebaran data yang rendah dan tidak adanya kesenjangan yang cukup besar dari nilai tertinggi dan nilai terendah. Nilai ini menunjukkan aplikasi mudah dipahami.

Tabel 9. Descriptive S. Understandability

\begin{tabular}{lc}
\hline \multicolumn{2}{c}{ Descriptive Statistic } \\
\hline Mean & 17,15 \\
Standard Deviation & 3,526 \\
Minimum & 6 \\
Maximum & 24 \\
Responden & 138 \\
\hline
\end{tabular}

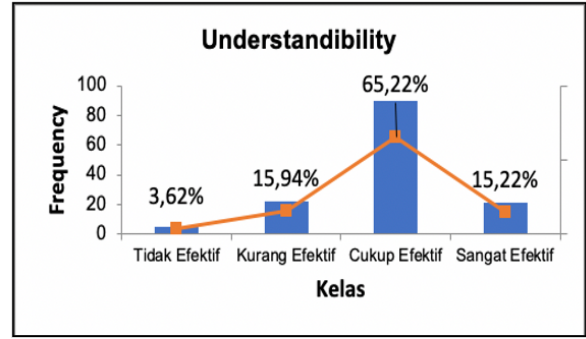

Gambar 9. Grafik Understandability

Sebaran data gambar 9 menjelaskan bahwa Understandability berada pada kategori cukup efektif sebesar $65,22 \%$ sedangkan sangat efektif sebesar $15,22 \%$, maka penjumlahan kedua kategori di atas sebesar 80,22\% dari 138 responden/mahasiswa yang menjawab setuju bahwa informasi, menu-menu dan tombol yang ada pada aplikasi ini mudah dipahami oleh pengguna.

\subsection{Learnability}

Berdasarkan Tabel 10 menunjukkan bahwa rata-rata (mean) learnabiliy adalah 14,65 dengan nilai maksimum adalah 20 dan nilai minimium adalah 5 , 
standart deviation atau standar deviasi adalah 2,451. Hasil analisis tersebut menunjukkan nilai standar deviasi lebih rendah dari pada nilai rata-rata maka sebaran data yang rendah dan tidak adanya kesenjangan yang cukup besar dari nilai tertinggi dan terendah. Nilai ini menunjukan aplikasi mudah dipelajari.

Tabel 10. Descriptive Statistical Learnability

\begin{tabular}{lc}
\hline \multicolumn{2}{c}{ Descriptive Statistic } \\
\hline Mean & 14,65 \\
Standard Deviation & 2,451 \\
Minimum & 5 \\
Maximum & 20 \\
Responden & 138 \\
\hline
\end{tabular}

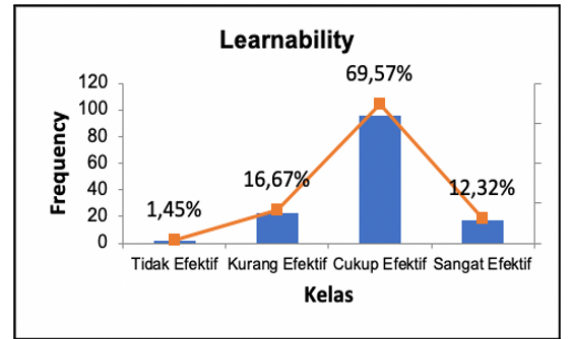

Gambar 10. Grafik Learnability

Sebaran data gambar 10 menjelaskan bahwa learnability berada pada kategori cukup efektif sebesar $69,57 \%$ sedangkan sangat efektif sebesar $12,32 \%$, maka hasil kedua kategori di atas sebesar 81,89\% dari 138 responden/mahasiswa yang menjawab setuju bahwa aplikasi mudah dipelajari oleh pengguna.

\subsection{Operability}

Berdasarkan Tabel 11 menunjukkan bahwa rata-rata (mean) operability adalah 8,77 dengan nilai maksimum adalah 12 dan nilai minimium adalah 3 , standart deviation atau standar deviasi adalah 1,669. Hasil analisis tersebut menunjukkan nilai standar deviasi lebih rendah dari pada nilai rata-rata maka sebaran data yang rendah dan tidak adanya kesenjangan yang cukup besar dari nilai tertinggi dan terendah. Nilai ini menunjukkan aplikasi mudah dioperasikan.

Tabel 11. Descriptive Statistic Operability

\begin{tabular}{lc}
\hline \multicolumn{2}{c}{ Descriptive Statistic } \\
\hline Mean & 8,77 \\
Standard Deviation & 1,669 \\
Minimum & 3 \\
Maximum & 12 \\
Responden & 138 \\
\hline
\end{tabular}

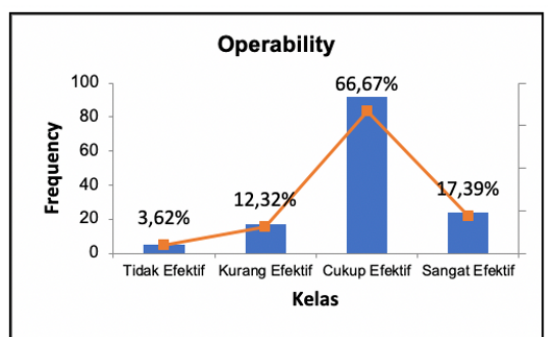

Gambar 11. Grafik Operability 
Sebaran data Gambar 11 menjelaskan bahwa operability berada pada kategori cukup efektif sebesar $66,67 \%$ sedangkan sangat efektif sebesar 17,39\%, maka jumlah dari kedua kategori sebesar 84,06\% dari 138 responden/mahasiswa yang menjawab setuju bahwa aplikasi dapat dioperasikan dengan mudah oleh pengguna.

\subsection{Attractiveness}

Berdasarkan Tabel 12 menunjukkan bahwa rata-rata (mean) attractiveness adalah 14,82 dengan nilai maksimum adalah 20 dan nilai minimium adalah 5, standart deviation atau standar deviasi adalah 2,579. Hasil analisis tersebut menunjukkan nilai standar deviasi lebih rendah dari pada nilai rata-rata maka sebaran data yang rendah dan tidak adanya kesenjangan yang cukup besar dari nilai tertinggi dan nilai terendah. Hal ini menunjukkan bahwa aplikasi bisa menarik perhatian pengguna.

Tabel 12. Descriptive Statistic Attractiveness

\begin{tabular}{lc}
\hline \multicolumn{2}{c}{ Descriptive Statistic } \\
\hline Mean & 14,82 \\
Standard Deviation & 2,579 \\
Minimum & 5 \\
Maximum & 20 \\
Responden & 138 \\
\hline
\end{tabular}

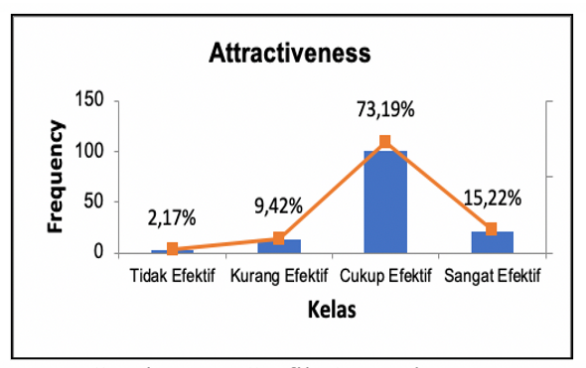

Gambar 12. Grafik Attractiveness

Sebaran data Gambar 12 menjelaskan bahwa attractiveness berada pada kategori cukup efektif sebesar 73,19\% sedangkan sangat efektif sebesar 15,22\%, maka jumlah dari kategori di atas seebesar $88,41 \%$ dari responden/mahasiswa yang menjawab setuju bahwa fitur-fitur aplikasi sangat menarik bagi pengguna.

\section{Efficiency}

Efficiency dari kualitas sistem informasi berdasarkan pada indikator time behaviour dari sistem layanan akademik ecampus IAIN Syaikh Abdurrahman Siddik Bangka Belitung deskripsinya adalah sebagai berikut: 
Berdasarkan Tabel 13 menunjukkan bahwa rata-rata (mean) time behavior adalah 5,05 dengan nilai maksimum adalah 8 dan nilai minimium adalah 2, standart deviation atau standar deviasi adalah 2,182. Hasil analisis tersebut menunjukkan nilai standar deviasi lebih rendah dari pada nilai rata-rata maka sebaran data yang rendah dan tidak adanya kesenjangan yang cukup besar dari nilai tertinggi dan nilai terendah. Nilai ini menunjukkan bahwa aplikasi mampu memberikan respon berapa second dalam pengolahan.

Tabel 13. Descriptive Statistic Time behavior

\begin{tabular}{lc}
\hline \multicolumn{2}{c}{ Descriptive Statistic } \\
\hline Mean & 5,05 \\
Standard Deviation & 2,182 \\
Minimum & 2 \\
Maximum & 8 \\
Responden & 138 \\
\hline
\end{tabular}

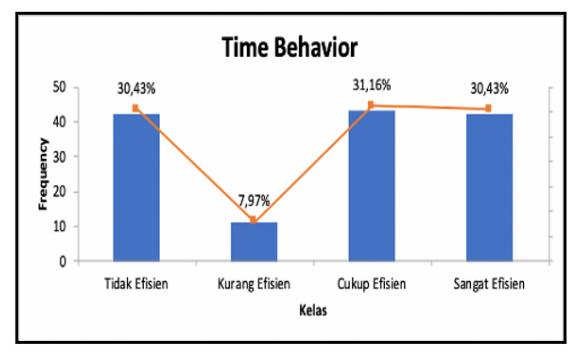

Gambar 13. Grafik Time behavior

Sebaran data Gambar 13 menjelaskan bahwa time behavior berada pada kategori cukup efisien sebesar $31,16 \%$ dan sangat efektif sebesar $30,43 \%$, maka apabila kedua kategori digabungkan sebesar $61,59 \%$ dari 138 responden yang menjawab lebih kecil dari 10 detik bahwa aplikasi cepat dalam memproses login dari pengguna.

\section{Kesimpulan}

Berdasarkan pada temuan dan pembahasan hasil penelitian diperoleh kesimpulan dari empat variabel standart ISO 9126 yang terdiri dari functionality, Reliability, Usability dan Eficiency yaitu sudah memberikan cukup efektif bagi mahasiswa yang menggunakan aplikasi ecampus IAIN Syaikh Abdurrahman Siddik Bangka Belitung.

Dengan adanya aplikasi ecampus semakin memudahkan kegiatan proses belajar mengajar untuk mahasiswa, dosen dan tenga kependidikan. Penelitian ini mengukur tingkat kualitas sistem dengan ISO 9126, namun hanya variabel functionality, Reliability, Usability dan Efficiency. Sehingga alangkah baiknya jika 
|PRIYANGgO KAUNIA RAHMAN | Analisis Tingkat Efektivitas Sistem...

penelitian selanjutnya mengikutsertakan variabel maintability dan portability. Penelitian ini diharapkan menjadi acuan bagi aplikasi ecampus dalam pengembangan ke depan yang lebih baik.

\section{Daftar Pustaka}

Mesa, Budi Hartono, and Johanes Fernandes Andry. "Evaluasi Tingkat Efektivitas Sistem Informasi Menggunakan Framework COBIT 5,” 2018.

Muhsin, Ahmad, and Zicko Pratama. "Analisis Efektivitas Mesin Cooling Tower Menggunakan Range and Approach." Opsi 11, no. 2 (2018): 119-24.

Rewah, Jein, and Reymon Rotikan. "Analisa Efektivitas Sistem Informasi Di Kantor Badan Kepegawaian Dan Diklat Kota Manado." CogITo Smart Journal 2, no. 2 (2016): 180-93.

Rozas, Indri Sudanawati, and Danar Ayu Ristyantie Effendy. "Mengukur Efektifitas Hasil Audit Teknologi Informasi COBIT 4.1 Berdasarkan Perspektif End User." Jurnal Link 17 (2012).

Arokiasamy, Anantha Raj A, and A G Abdullah. 2012. "Service Quality and Students' Satisfaction at Higher Learning Institutions: A Case Study of Malaysian University Competitiveness." International Journal of Management and Strategy 3 (5): 1-16.

Ayu, Putu Desiana Wulaning. 2017. "Analisis Pengukuran Tingkat Efektivitas Dan Efisiensi Sistem Informasi Manajemen Surat STIKOM Bali.” Jurnal Sistem Dan Informatika 11 (2).

Darmawan, Deni, and Kunkun Nur Fauzi. 2013. Sistem Informasi Manajemen. Pertama. Bandung: Rosda.

Hery Susanto. 2012. "Pengaruh Layanan Akademik Terhadap Kepuasan Mahasiswa Program Pascasarjana Universitas Terbuka Pada Unit Program Belajar Jarak Jauh (PBJJ) Mataram.” Jurnal Pendidikan Terbuka Dan Jarak Jauh 15 (2): $1-98$.

Irtanto, Irtanto. 2012. "Efektivitas Sistem Manajemen Mutu ISO 9001: 2008 Terhadap Kualitas Pelayanan

Administrasi Kependudukan Di Kota Blitar." Jurnal Bina Praja: Journal of Home Affairs Governance 4 (4): 261-72.

Nielsen, Lene. 2003. "A Model for Personas and Scenarios Creation." Roskilde, Denmark 71.

Pressman Roger, S. 2012. Rekayasa Perangkat Lunak. Yoyakarta: Andi.

Putri, Nilda Tri, Elita Amrina, and Adlina Safitri Helmi. 2015. "Pengaruh Akreditasi

Perguruan Tinggi Terhadap Kepuasan Dan Loyalitas Mahasiswa (Studi

Kasus: Fakultas Teknik Universitas Andalas)."

Rigawan, Gyanriscky, and Afriyeni Afriyeni. n.d. "Penerapan Sistem Informasi Bank Pada PT. Bank Central Asia Tbk (BCA)." 
Susanto, Eko Budi, M Faizal Kurniawan, and P A Christianto. 2017. "Integrasi Informasi Kesehatan Pada Instansi Kesehatan Di Kota Pekalongan Melalui Sistem Informasi Layanan Kesehatan.” Jurnal Litbang Kota Pekalongan 13. Sutabri, Tata. 2012. Konsep Sistem Informasi. Penerbit Andi.

Zyrmiak, Daniel. 2001. "Software Quality Function Deployment.," 2001. https://www.isixsigma.com/tools-templates/qfd-house-of-quality/softwarequality-function-deployment/. 